\title{
Gender-Related Differences in Iron Absorption by Preadolescent Children
}

\author{
JEROLD C. WOODHEAD, JEAN M. DRULIS, STEVEN E. NELSON, MORTEZA JANGHORBANI, \\ AND SAMUEL J. FOMON \\ Department of Pediatrics, College of Medicine, University of Iowa, Iowa City, Iowa 52242 and Department of \\ Medicine, University of Chicago, Chicago, Illinois 60637
}

\begin{abstract}
In a study of absorption of iron from meals by preadolescent children (Tanner stage 1 ), we had noted that erythrocyte incorporation of the extrinsic iron label was somewhat greater by girls than by boys. Although the difference was not significant, the observation seemed to warrant further study. Study A: A precisely determined quantity of ferrous sulfate enriched with the stable isotope ${ }^{58} \mathrm{Fe}$ was given without food to 15 boys and 15 girls (Tanner stage 1) after an overnight fast and was immediately followed by a dose of $70 \mathrm{mg}$ of ascorbic acid. ${ }^{58} \mathrm{Fe}$ enrichment of the erythrocytes was determined by inductively coupled plasma mass spectrometry at baseline and 14 and $42 \mathrm{~d}$ after administration of the ${ }^{58} \mathrm{Fe}$ dose. Geometric mean erythrocyte incorporation of the ${ }^{58} \mathrm{Fe}$ label was $35.2 \%$ of intake by boys and $45.0 \%$ of intake by girls. The difference was significant (analysis of covariance with serum ferritin as covariate, $p=0.035$ ). Study $B$ : Fifteen boys and 15 girls (Tanner stage 1) were fed a breakfast labeled with ${ }^{58} \mathrm{Fe}$. Geometric mean erythrocyte incorporation of the ${ }^{58} \mathrm{Fe}$ label was $14.8 \%$ of intake by boys and $24.7 \%$ of intake by girls. The difference was significant (analysis of covariance with serum ferritin as covariate, $p=0.004$ ). Because serum ferritin concentrations were similar in boys and girls, the gender-related difference in iron absorption (as reflected by erythrocyte incorporation of the label) does not appear to be explained by a difference in body stores of iron. We hypothesize that hormonal differences between boys and girls in Tanner stage 1 favor iron absorption by girls. (Pediatr Res 29: 435-439, 1991)
\end{abstract}

Abbreviations
MIR $_{58 / 57}$, mass isotope ratio ${ }^{58} \mathrm{Fe} /{ }^{57} \mathrm{Fe}$
MIR $_{0, M I R}$ M8/57 at baseline
NHANES II, Second National Health and Nutrition EX-
amination Survey

Data from NHANES II demonstrated that from 1976 to 1980 iron deficiency was more prevalent among males 11 to $15 \mathrm{y}$ of age $(12.1 \%$ iron deficient) than among females in the same age group (6.1\% iron deficient) (1). This finding was surprising because in older adolescents and adults prevalence of iron deficiency is much greater among females than among males. For example, in NHANES II, in the age category 15 to $19 \mathrm{y}, 14.2 \%$ of females and only $0.1 \%$ of males were iron deficient. Sex-

Received October 18, 1990; January 7, 1991.

Supported in part by USPHS Grants RR 59 and DK-26678 and the Children's Miracle Network Telethon.

Correspondence and reprint requests: Samuel J. Fomon, M.D., Professor, Department of Pediatrics, College of Medicine, University of lowa, lowa City, IA 52242. specific prevalence data for iron deficiency of subjects less than 11 y of age were not reported.

The more satisfactory iron nutritional status of girls than of boys in the age range 11 to $15 \mathrm{y}$ was also surprising because the same survey demonstrated that dietary intake of iron in each age interval from 6 to $15 \mathrm{y}$ of age was greater by boys than by girls (2). The mean iron intake in NHANES II for individuals from 12 to $15 \mathrm{y}$ of age was $6.66 \mathrm{mg} / \mathrm{d}$ for boys and $6.21 \mathrm{mg} / \mathrm{d}$ for girls.

In a study of absorption of nonheme iron from a simulated school lunch (3), we noted that erythrocyte incorporation of the extrinsic nonheme iron tag was somewhat greater by girls than by boys. The subjects were 16 children, eight boys and eight girls, ranging in age from 7.3 to $10.2 \mathrm{y}$. Each child consumed lunches containing a beef patty for 3 consecutive $d$ at one time and lunches with a beef-soy patty for 3 consecutive $d$ at another time. Each lunch was labeled with an iron isotope. Based on average values for the two series of lunches for each child, geometric mean erythrocyte incorporation of the extrinsic tag was $1.85 \%$ of the dose for girls and $1.14 \%$ of the dose for boys. The difference was not statistically significant (analysis of covariance with serum ferritin concentration as the covariate, $p=0.13$ ), and it was not possible to exclude an order of treatment effect.

Because we could find no report concerning a prepubertal sexrelated difference in iron absorption in human subjects or in experimental animals, we decided to explore the possibility that iron absorption was different in boys and girls at the stage of sexual development before testicular enlargement was evident in boys or breast buds were detectable in girls.

\section{MATERIALS AND METHODS}

Two studies were carried out, study A from October 9, 1987 to January 28, 1988, and study B from October 27, 1989 to March 2, 1990. The protocols were reviewed and approved by the University of Iowa Committee on Research Involving Human Subjects. Informed consent was obtained from at least one parent of each child and from the child.

The children were recruited through newspaper advertisements and personal contacts. All children were healthy. In each instance, height and weight were between the 5 th and 95 th centile for age of the NHANES II reference data (4). The children were admitted to the General Clinical Research Center of the University of Iowa in sex-specific cohorts of approximately five children. Subjects were admitted by $1600 \mathrm{~h}$ on Friday and discharged at approximately $1100 \mathrm{~h}$ on Saturday. After admission on Friday, a complete physical examination, including evaluation of sexual maturity (5), was performed, and a sample of venous blood (7 $\mathrm{mL}$ ) was obtained. A second blood sample of similar size was obtained $13 \mathrm{~d}$ later.

Anthropometry and Tanner Staging. Height was measured to the nearest $0.1 \mathrm{~cm}$ with a wall-mounted stadiometer. Weight was measured to the nearest $100 \mathrm{~g}$ on a calibrated scale.

Girls were identified as prepubertal (Tanner stage 1) if there 
was no evidence of breast bud. Boys were identified as prepubertal (Tanner stage 1) if examination of genitalia revealed testicular volume less than $4 \mathrm{~cm}^{3}$, as determined by measurement with a Prader orchiometer (6).

Study A-Meals and Stable Isotope Administration. Meals. Dinner consisted of turkey nuggets, french fried potatoes, corn, sliced peaches, and $2 \%$ fat milk. An evening snack consisted of potato chips and 7Up. Breakfast consisted of toaster waffles, applesauce, and hot chocolate with marshmallow. Foods other than the standard meals were not permitted. There was no restriction of water intake.

Isotope administration. Metallic iron powder $\left(84.58 \mathrm{wt} \%{ }^{58} \mathrm{Fe}\right)$ obtained from Oak Ridge National Laboratory (Oak Ridge, TN) was used to prepare an aqueous solution of ferrous sulfate (7), providing $1 \mathrm{mg}$ of iron per $\mathrm{mL}$. The ferrous sulfate solution was sealed in multiple-dose ampules under nitrogen and stored in the dark until used.

At 0700 on Saturday morning, each child received a precisely weighed quantity of the ${ }^{58} \mathrm{Fe}$-enriched ferrous sulfate solution, providing approximately $2.0 \mathrm{mg}$ of iron and $1.7 \mathrm{mg}$ of ${ }^{58} \mathrm{Fe}$. The ${ }^{58} \mathrm{Fe}$-enriched ferrous sulfate solution (about $2 \mathrm{~g}$ ) was drawn up into a tared syringe, and the weight of the syringe and solution was recorded. The solution was dispensed into $60 \mathrm{~mL}$ of orangeflavored Kool-Aid without added vitamin C; the syringe was rinsed twice, each time with $2 \mathrm{~mL}$ of distilled water; the rinsings were added to the Kool-Aid; and the Kool-Aid was consumed. An additional $60 \mathrm{~mL}$ of Kool-Aid with $70 \mathrm{mg}$ of vitamin $\mathrm{C}$ was added to the glass, mixed by swirling, and consumed. At $0900 \mathrm{~h}$, the previously described breakfast was eaten. At $1100 \mathrm{~h}$, the children were discharged from the General Clinical Research Center.

Study B-Meals, Stable Isotope Administration. Meals. Dinner consisted of turkey nuggets, mashed potatoes, corn, a cupcake, and $2 \%$ fat milk. An evening snack consisted of potato chips, a peanut butter cookie, and 7Up. Breakfast consisted of white bread toast $(25 \mathrm{~g})$, grape jelly $(14 \mathrm{~g})$, reconstituted frozen orange juice $(240 \mathrm{~mL})$, and a lean ground beef patty $(60 \mathrm{~g})$. Foods other than the standard meals were not permitted. There was no restriction of water intake.

Isotope administration. ${ }^{58} \mathrm{Fe}$-enriched ferrous sulfate was prepared as described for study A, except that the metallic iron powder obtained from Oak Ridge was 60.28 wt $\%{ }^{58} \mathrm{Fe}$.

At $0800 \mathrm{~h}$ on Saturday morning, each child received with breakfast a precisely weighed quantity (approximately $1.25 \mathrm{~g}$ ) of ${ }^{58} \mathrm{Fe}$-enriched ferrous sulfate solution providing approximately $1.9 \mathrm{mg}$ of iron and $1.1 \mathrm{mg}$ of ${ }^{58} \mathrm{Fe}$. The solution was dispensed into $120 \mathrm{~mL}$ of orange juice, and the syringe was rinsed twice, each time with $2 \mathrm{~mL}$ of distilled water. Rinsings were added to the orange juice, which was then consumed. An additional 120 $\mathrm{mL}$ of orange juice were then added to the glass, mixed by swirling within the glass, and consumed.

Analyses of Blood. $\mathrm{Hb}$ concentration was determined by the cyanmethemoglobin method (catalog no. 368555; Boehringer Mannheim Diagnostics, Indianapolis, IN), and serum ferritin concentration was determined by RIA using the Micromedic Ferritin RIA kit (catalog no. D-4401; Micromedic Systems, Inc., Horsham, PA). MIR $58 / 57$ was determined by inductively coupled plasma mass spectrometry, using the Elan 250 ICP/MS System (Sciex Inc., Thornhill, Canada) operated in the isotope ratio mode. The method has been described in detail (7).

Calculation of Quantity of Administered ${ }^{58} \mathrm{Fe}$ Incorporated into Erythrocytes. MIR $_{0}$ and MIR $_{58 / 57}$ at a specified time after isotope administration are used in the following equation to determine the quantity of administered ${ }^{58} \mathrm{Fe}$ incorporated into erythrocytes:

$$
{ }^{58} \mathrm{Fe}_{\text {inc }}=\frac{\left(\mathrm{MIR}_{\mathrm{t}}-\mathrm{MIR}_{0}\right) \times \mathrm{Fe}_{\text {circ }} \times 0.02183}{1+\left(\mathrm{MIR}_{\mathrm{t}}-\mathrm{MIR}_{0}\right) \times 0.02183}
$$

where ${ }^{58} \mathrm{Fe}_{\text {inc }}$ is the quantity of the ${ }^{58} \mathrm{Fe}$ label incorporated into erythrocytes, expressed in $\mathrm{mg}, \mathrm{MIR}_{\mathrm{t}}$ is the determined $\mathrm{MIR}_{58 / 57}$ at time $t$ after dosing, $\mathrm{Fe}_{\text {circ }}$ is the calculated quantity of total circulating iron $(\mathrm{mg})$ at time $\mathrm{t}$, and 0.02183 is the natural abundance (wt fraction) of ${ }^{57} \mathrm{Fe}$. The quantity of circulating iron $\left(\mathrm{Fe}_{\text {circ }}\right)$ was estimated as follows:

$$
\mathrm{Fe}_{\text {circ }}=\mathrm{BV} \times \mathrm{Hb} \times 3.47,
$$

where $\mathrm{Hb}$ is $\mathrm{Hb}$ concentration in $\mathrm{g} / 100 \mathrm{~mL}, 3.47$ is the concentration of iron in $\mathrm{Hb}(\mathrm{mg} / \mathrm{g})$, and $\mathrm{BV}$ is blood volume in $\mathrm{mL}$ calculated for each subject from weight in $\mathrm{kg}$ and height in $\mathrm{cm}$ with the regression equations of Linderkamp et al. (8):

$$
\text { Boys: } \log \mathrm{BV}=0.6459 \log \mathrm{wt}+0.002743 \mathrm{ht}+2.0324
$$$$
\text { Girls: } \log \mathrm{BV}=0.6412 \log w \mathrm{wt}+0.001270 \mathrm{ht}+2.2169
$$

Statistical Analysis. Because the data are normally distributed, arithmetic means are presented for serum ferritin concentrations and percentage incorporation of the ${ }^{58} \mathrm{Fe}$ label into erythrocytes. Geometric means are also included to facilitate comparisons with data in the literature.

Percentage incorporation of the ${ }^{58} \mathrm{Fe}$ label by males and females was compared by analysis of covariance with serum ferritin concentration as the covariate.

\section{RESULTS}

Study $A$. Fifteen boys and 16 girls were enrolled. One girl vomited soon after consuming the dose of iron and was therefore eliminated from the cohort. Thus, 15 boys and 15 girls completed the study.

Data on age, height, weight, $\mathrm{Hb}$ concentration, serum ferritin concentration, $\mathrm{MIR}_{0}$, and $\mathrm{MIR}_{58 / 57}$ on the 13 th $\mathrm{d}$ after receiving the ${ }^{58} \mathrm{Fe}$-enriched ferrous sulfate are presented in Table 1 . The difference in mean age of the boys $(118 \mathrm{mo})$ and girls $(108 \mathrm{mo})$ was not significant $(t$ test, $p=0.102$ ). The values for $\mathrm{Hb}$ and serum ferritin listed in Table 1 are the averages of two determinations-one at baseline and one $13 \mathrm{~d}$ after administration of the ${ }^{58} \mathrm{Fe}$-enriched ferrous sulfate. Mean $\mathrm{Hb}$ concentration was $13.5 \mathrm{~g} / \mathrm{dL}$ for boys, and $13.4 \mathrm{~g} / \mathrm{dL}$ for girls. Mean serum ferritin concentration was $41.2 \mathrm{ng} / \mathrm{mL}$ for boys, and $39.5 \mathrm{ng} / \mathrm{mL}$ for girls. The differences in these values for boys and girls were not significant.

Five of the children (subjects A4, A9, A11, A23, and A27 in Table 1) had received meals labeled with ${ }^{58} \mathrm{Fe}$ during the summer of 1986 (June 24 through September 1) in a prior study (3). Four of these children (the exception was subject A27) had elevated MIR $_{0}$. Such elevated baseline values were to be anticipated. In adult subjects, at least $1 \mathrm{y}$ is required for an iron label that has been incorporated into erythrocytes to become equilibrated between erythrocytes and storage sites (9).

The regression of percent of the administered dose of ${ }^{58} \mathrm{Fe}$ incorporated into erythrocytes on serum ferritin concentration was statistically significant for boys $(r=-0.626, p=0.013)$, but not for girls $(r=-0.247, p=0.37)$. The corresponding regressions on the logarithm of serum ferritin concentration gave similar results $(r=-0.653, p=0.008$ for boys; $r=-0.256, p=0.36$ for girls).

The geometric mean value for percent of administered ${ }^{58} \mathrm{Fe}$ label incorporated into erythrocytes was 35.2 for boys and 45.0 for girls. The difference was statistically significant (analysis of covariance with serum ferritin as covariate, $p=0.035$ ).

Study $B$. Fifteen boys and 15 girls participated in the study. Data on age, height, weight, $\mathrm{Hb}$ concentration, serum ferritin concentration, and $\mathrm{MIR}_{0}$, and $\mathrm{MIR}_{58 / 57}$ on the 13th $\mathrm{d}$ after receiving the ${ }^{58} \mathrm{Fe}$-enriched ferrous sulfate are presented in Table 2. As in Table 1 , values for $\mathrm{Hb}$ and serum ferritin are the averages of the two determinations. Mean $\mathrm{Hb}$ concentration was $13.8 \mathrm{~g} /$ $\mathrm{dL}$ for boys and $13.6 \mathrm{~g} / \mathrm{dL}$ for girls. Mean serum ferritin concentration was $50.2 \mathrm{ng} / \mathrm{mL}$ for boys and $47.6 \mathrm{ng} / \mathrm{mL}$ for girls. The differences in these values for boys and girls were not significant.

Contrary to the findings in study $\mathrm{A}$, the difference in mean age of the boys $(114 \mathrm{mo})$ and girls $(102 \mathrm{mo})$ was significant $(t$ test, $p=0.002$ ). 
IRON ABSORPTION BY BOYS AND GIRLS

Table 1. Study A: erythrocyte incorporation of ${ }^{58} \mathrm{Fe}$ from reference dose of iron

\begin{tabular}{|c|c|c|c|c|c|c|c|c|c|}
\hline \multirow[b]{2}{*}{ Subject } & \multirow{2}{*}{$\begin{array}{l}\text { Age } \\
(\mathrm{mo})\end{array}$} & \multirow{2}{*}{$\begin{array}{c}\text { Weight } \\
(\mathrm{kg}) \\
\end{array}$} & \multirow{2}{*}{$\begin{array}{c}\text { Height } \\
(\mathrm{cm})\end{array}$} & \multirow{2}{*}{$\begin{array}{c}\mathrm{Hb} \\
(\mathrm{g} / \mathrm{dL})\end{array}$} & \multirow{2}{*}{$\begin{array}{c}\text { Ferritin } \\
\text { (ng/ } \\
\text { mL) }\end{array}$} & \multicolumn{2}{|c|}{$\mathrm{MIR}_{58 / 57}$} & \multicolumn{2}{|c|}{${ }^{58} \mathrm{Fe}$ incorporation } \\
\hline & & & & & & $\mathrm{MIR}_{0}$ & $\mathrm{MIR}_{13}{ }^{*}$ & $\mathrm{mg}$ & $\%$ of dose \\
\hline \multicolumn{10}{|l|}{ Males } \\
\hline Al & 127 & 30.3 & 143.0 & 13.1 & 52 & 0.1478 & 0.1806 & 0.795 & 44.6 \\
\hline $\mathrm{A} 2$ & 93 & 23.1 & 125.0 & 13.6 & 42 & 0.1475 & 0.1928 & 0.841 & 47.4 \\
\hline A3 & 118 & 29.3 & 134.0 & 13.6 & 46 & 0.1478 & 0.1759 & 0.663 & 38.7 \\
\hline A4 & 137 & 30.3 & 139.0 & 14.4 & 24 & 0.1503 & 0.1832 & 0.865 & 50.4 \\
\hline A5 & 139 & 38.2 & 145.0 & 13.2 & 30 & 0.1474 & 0.1653 & 0.514 & 29.4 \\
\hline A6 & 132 & 35.0 & 137.0 & 12.8 & 32 & 0.1477 & 0.1636 & 0.401 & 24.5 \\
\hline A7 & 121 & 33.6 & 146.0 & 13.4 & 25 & 0.1474 & 0.1810 & 0.927 & 54.2 \\
\hline A8 & 108 & 36.4 & 142.5 & 13.6 & 23 & 0.1476 & 0.1818 & 1.000 & 59.3 \\
\hline A9 & 106 & 30.6 & 135.0 & 13.1 & 43 & 0.1512 & 0.1740 & 0.545 & 31.5 \\
\hline A 10 & 108 & 25.7 & 128.2 & 13.8 & 80 & 0.1474 & 0.1612 & 0.280 & 16.7 \\
\hline Al1 & 124 & 36.5 & 139.6 & 13.9 & 46 & 0.1506 & 0.1704 & 0.550 & 31.8 \\
\hline A 12 & 105 & 50.4 & 137.7 & 13.5 & 47 & 0.1473 & 0.1637 & 0.530 & 32.1 \\
\hline A 13 & 103 & 40.1 & 134.7 & 13.4 & 50 & 0.1470 & 0.1651 & 0.491 & 28.4 \\
\hline Al4 & 123 & 38.2 & 137.3 & 13.8 & 38 & 0.1478 & 0.1710 & 0.640 & 38.5 \\
\hline A 15 & 123 & 31.4 & 146.7 & 13.6 & 38 & 0.1472 & 0.1664 & 0.484 & 28.2 \\
\hline Mean & 118 & 33.9 & 138.0 & 13.5 & 41 & & & 0.635 & 37.0 \\
\hline $\mathrm{SD}$ & 13 & 6.6 & 6.2 & 0.4 & 14 & & & 0.208 & 12.0 \\
\hline \multicolumn{3}{|c|}{ Geometric mean } & & & 39 & & & & 35.2 \\
\hline \multicolumn{10}{|l|}{ Females } \\
\hline A 16 & 109 & 38.4 & 142.5 & 14.0 & 39 & 0.1475 & 0.1782 & 0.831 & 50.3 \\
\hline A 17 & 114 & 48.8 & 144.0 & 13.9 & 60 & 0.1477 & 0.1708 & 0.754 & 42.5 \\
\hline A18 & 91 & 20.3 & 124.0 & 12.5 & 45 & 0.1472 & 0.2088 & 0.958 & 55.6 \\
\hline A.19 & 104 & 36.1 & 134.5 & 13.4 & 43 & 0.1468 & 0.1895 & 1.070 & 61.8 \\
\hline $\mathrm{A} 20$ & 93 & 29.0 & 125.7 & 12.9 & 52 & 0.1478 & 0.1684 & 0.418 & 24.7 \\
\hline A21 & 91 & 27.2 & 128.3 & 12.0 & 30 & 0.1475 & 0.1972 & 0.885 & 53.2 \\
\hline A22 & 88 & 26.7 & 128.3 & 13.4 & 28 & 0.1478 & 0.2096 & 1.243 & 74.2 \\
\hline A23 & 122 & 43.5 & 143.7 & 14.6 & 60 & 0.1529 & 0.1796 & 0.815 & 48.1 \\
\hline A24 & 133 & 52.3 & 148.8 & 14.9 & 27 & 0.1474 & 0.1680 & 0.763 & 44.9 \\
\hline A 25 & 130 & 39.6 & 145.4 & 12.9 & 36 & 0.1468 & 0.1670 & 0.530 & 30.8 \\
\hline A26 & 129 & 29.5 & 134.5 & 14.4 & 32 & 0.1476 & 0.1870 & 0.925 & 55.0 \\
\hline $\mathrm{A} 27$ & 130 & 49.9 & 154.0 & 13.7 & 28 & 0.1481 & 0.1672 & 0.647 & 37.4 \\
\hline A28 & 86 & 28.0 & 125.7 & 12.9 & 30 & 0.1473 & 0.1811 & 0.660 & 40.0 \\
\hline A29 & 95 & 27.8 & 134.3 & 13.8 & 38 & 0.1474 & 0.1846 & 0.817 & 48.8 \\
\hline A30 & 109 & 29.5 & 143.5 & 12.4 & 45 & 0.1475 & 0.1757 & 0.563 & 32.5 \\
\hline Mean & 108 & 35.1 & 137.1 & 13.4 & 40 & & & 0.792 & 46.7 \\
\hline $\mathrm{SD}$ & 17 & 9.8 & 9.5 & 0.8 & 11 & & & 0.214 & 12.8 \\
\hline \multicolumn{2}{|c|}{ Geometric mean } & & & & 38 & & & & 45.0 \\
\hline
\end{tabular}

${ }^{*} \mathrm{MIR}_{13}, \mathrm{MIR}_{58 / 57}$ on the 13 th $\mathrm{d}$ after receiving the ${ }^{58} \mathrm{Fe}$-enriched ferrous sulfate.

Four of the children in study B (subjects B3, B4, B16, and B18) had participated 22 to 25 mo earlier in study A (subjects $\mathrm{A} 2, \mathrm{~A} 10, \mathrm{~A} 22$, and A18, respectively). Subjects B1, B4, B16, $\mathrm{B} 26$, and $\mathrm{B} 27$ had been given ${ }^{58} \mathrm{Fe}$ in a study (unpublished) carried out between study A and study B. All of these subjects except B1 had elevated values for MIR $_{0}$.

The regression of percent of the administered dose of ${ }^{58} \mathrm{Fe}$ incorporated into erythrocytes on serum ferritin concentration was significant both for boys $(r=-0.545, p=0.035)$ and girls $(r$ $=-0.676, p=0.006)$. The corresponding regressions on the logarithm of serum ferritin concentration gave similar results $(r$ $=-0.657, p=0.008$ for boys; $r=-0.660, p=0.007$ for girls).

The geometric mean value for percent of administered ${ }^{58} \mathrm{Fe}$ label incorporated into erythrocytes was 14.8 for boys and 24.7 for girls. The difference was statistically significant (analysis of covariance with serum ferritin as covariate, $p=0.004$ ).

\section{DISCUSSION}

Iron exists within the body in two major categories: functional (in $\mathrm{Hb}$, myoglobin, and iron-containing enzymes) and storage (in ferritin and hemosiderin) (10). The quantity of storage iron in adult subjects is indicated both by the serum ferritin concentration and the extent of absorption of iron from an orally administered reference dose of an inorganic iron salt (11). The relationships established for adults are useful in interpreting our findings in preadolescent children.

The geometric mean serum ferritin concentration $(\mathrm{ng} / \mathrm{mL})$ in study A was 39 for boys and 38 for girls and, in study B, 48 for boys and 45 for girls. In adult subjects, when serum ferritin concentrations are $>12 \mathrm{ng} / \mathrm{mL}$, serum ferritin of $1 \mathrm{ng} / \mathrm{mL}$ reflects storage iron of $10 \mathrm{ng}$ (12). Thus, the geometric mean serum ferritin concentrations of $34 \mathrm{ng} / \mathrm{mL}$ in premenopausal women and $94 \mathrm{ng} / \mathrm{mL}$ in men (11) reflect iron stores of 340 and 940 mg, respectively.

Assuming that serum ferritin concentration reflects iron stores per unit of fat-free body mass, it seems likely that, per unit of fat-free body mass, iron stores of the preadolescent boys and girls in our studies were somewhat greater than those of premenopausal women, but substantially less than those of adult males.

Several investigators have reported on the absorption of iron by nonanemic fasting adults given a reference dose of iron. Generally, $3 \mathrm{mg}$ of iron in the form of ferrous sulfate or ferrous ascorbate and about $30 \mathrm{mg}$ of ascorbic acid are given to fasting subjects and the extent of iron absorption is estimated from the radioactivity of blood obtained $2 \mathrm{wk}$ after administration of the radioactively tagged reference dose. In calculating percentage absorption, it is assumed that $80(11), 90(13)$, or $100 \%(14,15)$ of the absorbed iron has been incorporated into erythrocytes during the $2 \mathrm{wk}$ after consumption of the reference dose. 
Table 2. Study B: erythrocyte incorporation of ${ }^{58} \mathrm{Fe}$ fed with breakfast

\begin{tabular}{|c|c|c|c|c|c|c|c|c|c|}
\hline \multirow[b]{2}{*}{ Subject } & \multirow{2}{*}{$\begin{array}{c}\text { Age } \\
(\mathrm{mo})\end{array}$} & \multirow{2}{*}{$\begin{array}{c}\text { Weight } \\
(\mathrm{kg})\end{array}$} & \multirow{2}{*}{$\begin{array}{l}\text { Height } \\
(\mathrm{cm})\end{array}$} & \multirow{2}{*}{$\begin{array}{c}\mathrm{Hb} \\
(\mathrm{g} / \mathrm{dL})\end{array}$} & \multirow{2}{*}{$\begin{array}{c}\text { Ferritin } \\
\text { (ng/ } \\
\text { mL) }\end{array}$} & \multicolumn{2}{|c|}{$\mathrm{MIR}_{58 / 57}$} & \multicolumn{2}{|c|}{${ }^{58} \mathrm{Fe}$ incorporation } \\
\hline & & & & & & $\operatorname{MIR}_{0}$ & $\mathrm{MIR}_{13}{ }^{*}$ & $\mathrm{mg}$ & $\%$ of dose \\
\hline \multicolumn{10}{|l|}{ Males } \\
\hline B1 & 111 & 25.7 & 131.4 & 12.3 & 57 & 0.1480 & 0.1534 & 0.101 & 8.8 \\
\hline $\mathrm{B} 2$ & 100 & 27.7 & 132.0 & 13.6 & 40 & 0.1463 & 0.1575 & 0.244 & 21.3 \\
\hline B3 & 118 & 28.3 & 134.5 & 14.9 & 64 & 0.1708 & 0.1795 & 0.215 & 18.8 \\
\hline B4 & 130 & 30.3 & 137.3 & 14.2 & 76 & 0.1591 & 0.1662 & 0.177 & 15.7 \\
\hline B5 & 105 & 24.3 & 128.2 & 13.0 & 43 & 0.1457 & 0.1507 & 0.094 & 8.4 \\
\hline B6 & 105 & 27.8 & 123.9 & 13.6 & 81 & 0.1464 & 0.1519 & 0.114 & 10.1 \\
\hline B7 & 121 & 33.2 & 144.8 & 14.5 & 50 & 0.1467 & 0.1562 & 0.269 & 23.8 \\
\hline B8 & 120 & 40.2 & 139.7 & 15.5 & 44 & 0.1467 & 0.1534 & 0.223 & 19.6 \\
\hline B9 & 119 & 36.0 & 135.9 & 13.5 & 46 & 0.1466 & 0.1529 & 0.166 & 14.7 \\
\hline $\mathrm{B} 10$ & 105 & 29.7 & 129.5 & 13.8 & 34 & 0.1463 & 0.1554 & 0.207 & 18.3 \\
\hline B11 & 131 & 36.8 & 143.5 & 14.6 & 61 & 0.1467 & 0.1507 & 0.121 & 10.7 \\
\hline B12 & 122 & 29.7 & 129.5 & 13.6 & 52 & 0.1460 & 0.1541 & 0.182 & 16.2 \\
\hline B13 & 112 & 31.9 & 139.7 & 14.2 & 22 & 0.1463 & 0.1643 & 0.472 & 42.2 \\
\hline B14 & 102 & 36.4 & 132.1 & 12.6 & 36 & 0.1467 & 0.1560 & 0.224 & 19.9 \\
\hline B15 & 110 & 32.4 & 132.8 & 13.1 & 48 & 0.1479 & 0.1499 & 0.047 & 4.1 \\
\hline Mean & 114 & 31.4 & 134.3 & 13.8 & 50 & & & 0.190 & 16.8 \\
\hline $\mathrm{SD}$ & 10 & 4.5 & 5.8 & 0.9 & 16 & & & 0.100 & 8.9 \\
\hline Geome & mean & & & & 48 & & & & 14.8 \\
\hline \multicolumn{10}{|c|}{ Females } \\
\hline B16 & 115 & 33.2 & 139.2 & 12.2 & 34 & 0.1786 & 0.1939 & 0.331 & 29.1 \\
\hline B17 & 98 & 27.7 & 125.9 & 14.2 & 64 & 0.1460 & 0.1561 & 0.217 & 18.9 \\
\hline B18 & 116 & 25.8 & 139.0 & 13.5 & 58 & 0.1811 & 0.1913 & 0.207 & 18.4 \\
\hline B19 & 114 & 28.9 & 138.0 & 13.9 & 66 & 0.1457 & 0.1554 & 0.219 & 19.2 \\
\hline B20 & 101 & 22.8 & 124.2 & 14.3 & 30 & 0.1451 & 0.1672 & 0.422 & 37.4 \\
\hline B21 & 86 & 25.4 & 123.7 & 14.8 & 63 & 0.1460 & 0.1581 & 0.254 & 22.6 \\
\hline B22 & 103 & 25.4 & 123.2 & 13.8 & 34 & 0.1466 & 0.1742 & 0.540 & 48.5 \\
\hline B23 & 100 & 28.8 & 129.0 & 14.2 & 48 & 0.1468 & 0.1547 & 0.177 & 15.6 \\
\hline B24 & 94 & 25.4 & 122.0 & 12.9 & 40 & 0.1459 & 0.1636 & 0.324 & 29.2 \\
\hline B25 & 91 & 21.5 & 115.6 & 12.5 & 80 & 0.1462 & 0.1543 & 0.127 & 11.3 \\
\hline B26 & 106 & 37.2 & 135.9 & 14.2 & 47 & 0.1486 & 0.1633 & 0.394 & 35.2 \\
\hline B27 & 106 & 35.8 & 135.9 & 13.8 & 42 & 0.1492 & 0.1636 & 0.367 & 32.8 \\
\hline B28 & 92 & 29.7 & 123.2 & 12.2 & 32 & 0.1468 & 0.1606 & 0.264 & 23.2 \\
\hline B29 & 92 & 24.8 & 127.0 & 13.4 & 44 & 0.1461 & 0.1638 & 0.336 & 29.8 \\
\hline B30 & 115 & 29.9 & 134.0 & 14.4 & 32 & 0.1465 & 0.1575 & 0.259 & 23.0 \\
\hline Mean & 102 & 28.2 & 129.1 & 13.6 & 48 & & & 0.296 & 26.3 \\
\hline $\mathrm{SD}$ & 10 & 4.5 & 7.4 & 0.8 & 15 & & & 0.107 & 9.6 \\
\hline \multicolumn{2}{|c|}{ Geometric mean } & & & & 45 & & & & 24.7 \\
\hline
\end{tabular}

${ }^{*} \mathrm{MIR}_{13}, \mathrm{MIR}_{58 / 57}$ on the 13 th $\mathrm{d}$ after receiving the ${ }^{58} \mathrm{Fe}$-enriched ferrous sulfate.

Cook et al. (11) determined absorption of a reference dose of iron by 30 women 18 to 35 y of age. The subjects were in satisfactory iron nutritional status as judged by hematocrit greater than 36 and transferrin saturation greater than $20 \%$. Geometric mean serum ferritin was $27 \mathrm{ng} / \mathrm{mL}$. Geometric mean absorption of iron from the reference dose was reported as $28 \%$-corresponding to erythrocyte incorporation of $22 \%$. In most studies of erythrocyte incorporation of iron from a reference dose, some of the subjects were iron deficient or were frequent blood donors (13-16). In these studies, geometric mean absorption of the test dose of iron has often been greater than $40 \%$ of the dose.

It therefore appears that the preadolescent children who participated in study A absorbed a greater percentage of a reference dose of iron than would have been anticipated with adults of similar iron nutritional status. The greater absorption by the preadolescent children may be explained in part by the larger dose of ascorbic acid included with the reference dose of iron (the children received $70 \mathrm{mg}$; the adults about $30 \mathrm{mg}$ ).

In studies of adults, a substantially greater percentage of a radioiron tag is incorporated into erythrocytes when the tag is administered in the form of a reference dose (i.e., without food) than when the tag is administered with a meal (13-16). The lesser erythrocyte incorporation of iron when iron is administered with food presumably reflects the inhibitory effect of food on iron absorption. Thus, the greater percentage incorporation of ${ }^{58} \mathrm{Fe}$ in study A than in study B was to be anticipated.

Studies of adults fed meals containing enhancers of iron absorption $(14,17,18)$ suggest that adult subjects generally absorb a lesser percentage of the iron from such meals than we observed in study B. The difference in iron absorption between study B and the studies of adults may be explained by the greater bioavailability of iron in the meal fed in study $B$, which included two major enhancers of iron absorption (meat and orange juice) and no major inhibitors of iron absorption.

Our findings both in study A and in study B suggest that at Tanner stage 1 girls absorb iron more readily than do boys. Because serum ferritin concentrations were similar in boys and girls, the difference in absorption does not appear to be a consequence of smaller iron stores in the girls. We hypothesize that hormonal differences between boys and girls in Tanner stage 1 favor iron absorption by girls.

\section{REFERENCES}

1. Pilch SM, Senti FR 1984 Assessment of the Iron Nutritional Status of the US Population Based on Data Collected in the Second National Health and Nutrition Examination Survey, 1976-1980. Life Sciences Research Office, Federation of American Societies for Experimental Biology, Bethesda, MD

2. Carroll MD, Abraham S, Dresser CM 1983 Dietary intake source data: United States, 1976-80. National Center for Health Statistics. Vital and Health 
Statistics, Series 11, No 231. DHHS Pub No (PHS) 83-1681. Public Health Service, U.S. Government Printing Office, Washington, DC

3. Woodhead JC, Drulis JM, Rogers RR, Ziegler EE, Stumbo PJ, Janghorbani $\mathrm{M}$, Ting BTG, Fomon SJ 1988 Use of the stable isotope, ${ }^{58} \mathrm{Fe}$, for determining availability of nonheme iron in meals. Pediatr Res 23:495-499

4. Hamill PVV, Drizd TA, Johnson CL, Reed RB, Roche AF 1977 NCHS growth curves for children birth-18 years. National Center for Health Statistics, DHEW Pub No (PHS) 78-1650. Vital and Health Statistics, Series 11, No 165. Public Health Service, U.S. Government Printing Office, Washington, DC

5. Tanner JM 1962 Growth at Adolescence, 2nd Ed. Blackwell, Oxford, UK

6. Zachman M, Prader A, Kind HP, Häfliger H, Budliger H 1974 Testicular volume during adolescence: cross-sectional and longitudinal studies. Helv Paediat Acta 29:61-72

7. Janghorbani M, Ting BTG, Fomon SJ 1986 Erythrocyte incorporation of ingested stable isotope of iron $\left({ }^{58} \mathrm{Fe}\right)$. Am J Hematol 21:277-288

8. Linderkamp O, Versmold HT, Riegel KP, Betke K 1977 Estimation and prediction of blood volume in infants and children. Eur J Pediatr 125:227234

9. Bothwell TH, Chariton RW, Cook JD, Finch CA 1979 Iron Metabolism in Man. Blackwell Scientific Publications, Oxford, UK, p 252

10. Crichton RR 1975 Ferritin: structure, function and role in intracellular iron metabolism. In: Kief H (ed) Iron Metabolism and Its Disorders. American Elsevier Publishing Company, New York, pp 81-89

11. Cook JD, Lipschitz DA, Miles LEM, Finch CA 1974 Serum ferritin as a measure of iron stores in normal subjects. Am J Clin Nutr 27:681-689

12. Cook JD, Skikne BS 1982 Serum ferritin: a possible model for the assessment of nutrient stores. Am J Clin Nutr 35:1180-1185

13. Cook JD, Layrisse M, Martinez-Torres C, Walker R, Monsen E, Finch CA 1972 Food iron absorption measured by an extrinsic tag. J Clin Invest 51 $805-815$

14. Rossander L, Hallberg L, Björn-Rasmussen E 1979 Absorption of iron from breakfast meals. Am J Clin Nutr 32:2484-2489

15. Ballot D, Baynes RD, Bothwell TH, Gillooly M, MacFarlane BJ, MacPhail AP, Lyons G, Derman DP, Bezwoda WR, Torrance JD, Bothwell JE 1987 The effects of fruit juices and fruits on the absorption of iron from a rice meal. Br J Nutr 57:331-343

16. Hallberg L, Rossander L 1982 Effect of soy protein on nonheme iron absorp tion in man. Am J Clin Nutr 36:514-520

17. Cook JD, Monsen ER 1975 Food iron absorption. I. Use of a semisynthetic diet to study absorption of nonheme iron. Am J Clin Nutr 28:1289-1295

18. Cook JD, Monsen ER 1976 Food iron absorption in human subjects. III. Comparison of the effect of animal proteins on nonheme iron absorption. Am J Clin Nutr 28:859-867 